\title{
Cu(II) COMPLEXES WITH AN NNO FUNCTIONALIZED HYDRAZONE LIGAND: SYNTHESIS, CHARACTERIZATION AND BIOLOGICAL STUDIES
}

\author{
S. S. Kolate ${ }^{1,2}$, G. P. Waghulde ${ }^{2, *}$ and C. J. Patil ${ }^{3}$ \\ ${ }^{1}$ Department of Chemistry, Bhusawal Arts, Science and P. O. Nahata Comm. College, \\ Bhusawal-425 201, India. \\ ${ }^{2}$ Department of Chemistry, Dadasaheb Devidas Namdev Bhole College, \\ Bhusawal-425 201, MS, India. \\ ${ }^{3}$ Research Lab, Department of Chemistry, Smt. G. G. Khadse College, \\ Muktainagar-425 306, MS, India. \\ *E-mail: drgpwaghulade@gmail.com
}

\begin{abstract}
We report the synthesis of $\mathrm{Cu}(\mathrm{II})$ complexes with hydrazone ligands, 2-[(6-Nitro-benzothiazole-2-yl)hydrazonomethyl]-4,6-dichloro-phenol (BHD5) and 2-[(6-Nitro-benzothiazole-2-yl)-hydrazonomethyl]- 4-chlorophenol (BH5C). The synthesized compounds were characterized using elemental analyses, FT-IR, UV-Vis, ${ }^{1} \mathrm{H}-$ NMR, mass spectra, molar conductance and TGA. The stoichiometry of the copper complexes as 1:1[M:L] ratio and ligand behave as tridentate moiety with NNO donor atoms toward to the metal ion. The complexes have been assigned a tetrahedral geometry. The synthesized ligands and their copper complexes were screened for antibacterial activities against Gram-positive bacteria (Bacillus subtilis), Gram-negative bacteria (Salmonella typhi) and two funguses (Candida tropicalis and Kluyveromyces marxianus). The DPPH antioxidant activity shows that the copper complexes have a promising biological activity than their parent ligand.
\end{abstract}

Keywords: Hydrazone Ligand, Cu(II) Complexes, Biological and Antioxidant Activity.

(C) RASĀYAN. All rights reserved

\section{INTRODUCTION}

Thiazole and benzothiazole possess effective antimicrobial and antioxidant activity. Thiazoles are known as antioxidant and neuroprotective agent. ${ }^{1-3}$ Benzothiazole containing a 5-membered 1,3-thiazole ring which is fused into the benzene ring. They show excellent biological properties. ${ }^{4,5}$ Hydrazones are the azomethines, described by the tri-nuclear gathering $>\mathrm{C}=\mathrm{N}-\mathrm{N}<$ in their structure. ${ }^{6,7}$ Hydrazones contain azomethine linkage which is used as intermediates to synthesis some biologically active compounds. The hydrazone metal complexes are known for their excellent application in the biological and pharmaceutical fields as antimicrobial, antiviral, antitumor, antiparasitic and anti-inflammatory agents. ${ }^{8-10}$

In this work, we synthesized hydrazones ligand by condensation of 6-nitro-benzothiazole-2-yl-hydrazine with substituted different salicylaldehyde and study their coordination behavior, antimicrobial and antioxidant activity.

\section{Material and Methods}

\section{EXPERIMENTAL}

All organic solvents and inorganic substances employed in the present investigation is pure and analytical grade. Melting points take on Kumar KI-11-02 electrical melting point apparatus using one end seal capillary. The elemental contents $\mathrm{CHN}$ and S were carried out on Thermo- scientific (FLASH 2000) analyzer. The metal contents of the transition metal complexes were analyzed by gravimetric method. ${ }^{5}$ The IR spectrum was recorded on Nicolet iS5 FT-IR. The UV-Vis spectrum was taken on a Shimadzu UV-1800 spectrophotometer in DMF using $10^{-4} \mathrm{M}$ solution. The ${ }^{1} \mathrm{H}-\mathrm{NMR}$ spectral data were recorded in DMSO for $400 \mathrm{MHz}$ at SAIF, Panjab University. The mass spectrum was carried out on Waters micro-

Rasayan J. Chem., 13(2), 1008-1013(2020)

http://dx.doi.org/10.31788/RJC.2020.1325606

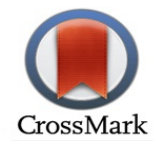


RASĀYAN J. Chem.

Vol. 13 | No. 2 |1008 - 1013| April - June | 2020

mass Q-TOF. The molar conductance carried out on CM model ELICO, 162 conductivity cell. Thermogravimetric studies were carried out in the temperature range RT-785 ${ }^{\circ} \mathrm{C}$ on a TGA 55 , TA instrument, USA.

\section{Synthesis of Ligands}

The hydrazone ligands were synthesized by under reflux of 6-Nitro-benzothiazole-2-yl-hydrazine $(0.01$ mmol) and substituted salicylaldehyde $(0.01 \mathrm{mmol})$ in the present of 2-3 droop glacial acetic acid using $20 \mathrm{ml}$ ethanol as reaction solvent ${ }^{5,11}$. Obtain precipitated was filtered, washed, recrystallized in ethanol and dried (Scheme-1).

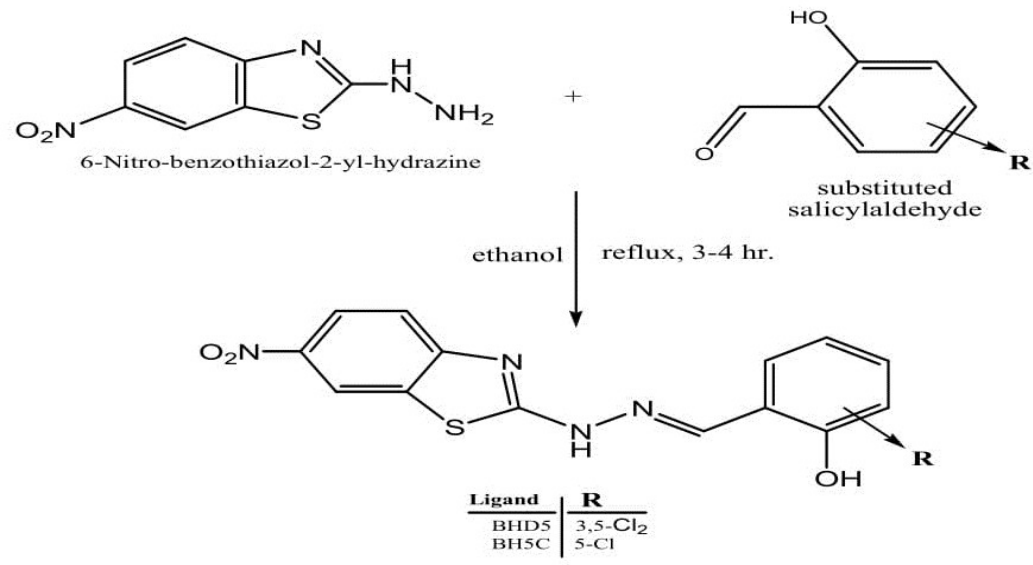

\section{BHD5}

Scheme-1: Synthesis of Hydrazone Ligands.

Yield 79\% ; m. p. $248^{\circ} \mathrm{C}$; Yellow solid; Anal. Calcd for $\mathrm{C}_{14} \mathrm{H}_{8} \mathrm{Cl}_{2} \mathrm{~N}_{4} \mathrm{O}_{3} \mathrm{~S}$ Calcd. (\%): C, 43.88; H, 2.10; N, 14.62; S, 8.17. Experimentally found (\%): C, 43.82; H, 2.25; N, 14.49; S, 7.59. FT-IR $\left(\mathrm{KBr}, \mathrm{cm}^{-1}\right): v(-$ NH) 3440, $v(\mathrm{C}=\mathrm{N})$ 1622, phenolic $v(\mathrm{C}-\mathrm{O})$ 1332, aromatic $v(\mathrm{C}-\mathrm{N})$ 1292, $v(\mathrm{~N}-\mathrm{N}) 1128,1042,918,745$, 660. Mass (ESI) $[\mathrm{M}]^{+}=382.9 \mathrm{amu}$.

\section{BH5C}

Yield 68\%; m.p. $239^{\circ} \mathrm{C}$; green solid; Anal. Calcd for $\mathrm{C}_{14} \mathrm{H}_{9} \mathrm{ClN}_{4} \mathrm{O}_{3} \mathrm{~S}$ Calcd. (\%): C, 48.21; H, 2.60; N, 16.06; S, 9.19. Experimentally found (\%): C, 48.01; H, 2.73; N, 15.91; S, 8.63. FT-IR $\left(\mathrm{KBr}, \mathrm{cm}^{-1}\right): v(-$ $\mathrm{NH}) 3447, v(\mathrm{C}=\mathrm{N}) 1622$, phenolic $v(\mathrm{C}-\mathrm{O}) 1329$, aromatic $v(\mathrm{C}-\mathrm{N}) 1292, v(\mathrm{~N}-\mathrm{N}) 1129,1042,880,745$, 673. Mass (ESI) $[\mathrm{M}]^{+}=349.01 \mathrm{amu}$.

\section{Synthesis of Copper(II) Complexes}

The copper(II) complexes were synthesized by the interaction between hydrazone ligands, BHD5 and BH5C ( $1 \mathrm{mmol})$ in $20 \mathrm{ml}$ ethanol with aqueous solution of copper(II) chloride dihydrate $\left(\mathrm{CuCl}_{2} \cdot 2 \mathrm{H}_{2} \mathrm{O}, 2\right.$ mmol) under reflux for 1-2 h., Obtain precipitated were filtered, washed with aqueous ethanol and dried (Scheme-2).

\section{Cu(BHD5)Cl}

Yield $79 \%$; m. p. $255^{\circ} \mathrm{C}$; greenish yellow solid. Anal. Calcd for $\mathrm{C}_{14} \mathrm{H}_{7} \mathrm{Cl}_{3} \mathrm{~N}_{4} \mathrm{CuO}_{3} \mathrm{~S}$ Calcd. (\%): C, 34.94; $\mathrm{H}, 1.57 ; \mathrm{N}, 11.64$.; S, 6.54; Cu, 13.21. Experimentally found (\%): C, 34.50; H, 1.82; N, 11.90; S, 6.07; $\mathrm{Cu}, 13.42$. FT-IR $\left(\mathrm{KBr}, \mathrm{cm}^{-1}\right): v(-\mathrm{NH}) 3434$, exocyclic $v(\mathrm{C}=\mathrm{N})$ 1606, endocyclic $v(\mathrm{C}=\mathrm{N})$ 1577, aromatic $v(\mathrm{C}-\mathrm{N}) 1285$, phenolic $v(\mathrm{C}-\mathrm{O}) 1341, v(\mathrm{~N}-\mathrm{N}) 1124, v(\mathrm{M}-\mathrm{O}) 617, v(\mathrm{M}-\mathrm{N}) 428 . \Lambda_{\mathrm{M}}\left(\Omega^{-1} \mathrm{~cm}^{2} \mathrm{~mol}^{-1}\right): 9.48$. Mass (ESI) $\left[\mathrm{M}^{+}\right]=481.9 \mathrm{amu}$.

\section{$\mathrm{Cu}(\mathrm{BH} 5 \mathrm{C}) \mathrm{Cl}$}

Yield 79\%; m.p. $269{ }^{\circ} \mathrm{C}$; dark green solid. Anal. Calcd for $\mathrm{C}_{14} \mathrm{H}_{8} \mathrm{Cl}_{2} \mathrm{~N}_{4} \mathrm{CuO}_{3} \mathrm{~S}$, Calcd. (\%): C, 37.64; $\mathrm{H}$, 1.80; N, 12.54.; S, 7.18; Cu, 14.21. Experimentally found (\%): C, 37.90; H, 1.89; N, 12.74; S, 6.94; Cu, 
RASĀYAN J. Chem.

Vol. 13 | No. 2 |1008 - 1013| April - June | 2020

13.92. FT-IR $\left(\mathrm{cm}^{-1}\right): v(-\mathrm{NH}) 3415$, exocyclic $v(\mathrm{C}=\mathrm{N}) 1616$, endocyclic $v(\mathrm{C}=\mathrm{N}) 1551$, aromatic $v(\mathrm{C}-\mathrm{N})$ 1284, phenolic $v(\mathrm{C}-\mathrm{O}) 1337, v(\mathrm{~N}-\mathrm{N}) 1104, v(\mathrm{M}-\mathrm{O}) 554, v(\mathrm{M}-\mathrm{N}) 424 . \mu_{\mathrm{eff}}(\mathrm{BM}): 1.94 . \Lambda_{\mathrm{M}}\left(\Omega^{-1} \mathrm{~cm}^{2} \mathrm{~mol}^{-}\right.$ $\left.{ }^{1}\right)$ : 11.06. Mass (ESI) $\left[\mathrm{M}^{+}\right]=445.9 \mathrm{amu}$.

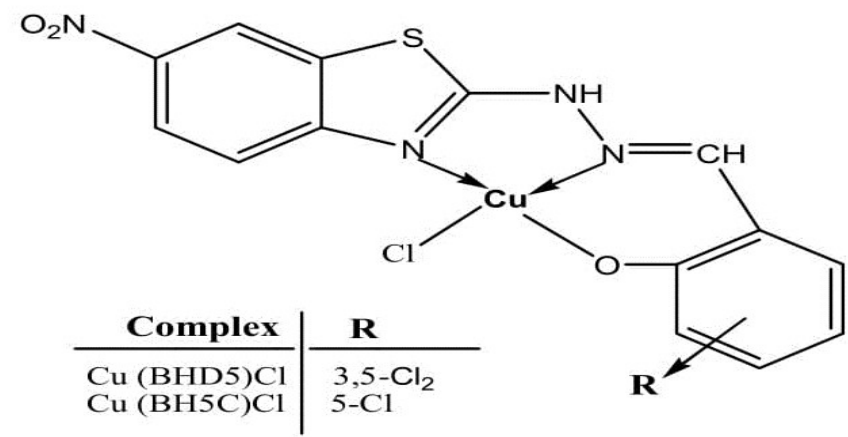

Scheme-2: Proposed Structure for $\mathrm{Cu}(\mathrm{BHD} 5) \mathrm{Cl}$ and $\mathrm{Cu}(\mathrm{BH} 5 \mathrm{C}) \mathrm{Cl}$ Complexes.

\section{Antimicrobial Activities}

The in vitro antimicrobial activity was evaluated against Bacillus subtilis as a Gram-positive bacterium, Salmonella typhi as a Gram-negative bacterium and two fungal strains, Aspergillus niger and Candida tropicalis by disk diffusion method. ${ }^{11,12}$ Streptomycin (antibacterial) and nystatin (antifungal) were used as standard drugs. The tested compounds were previously dissolved in DMF at $100 \mu \mathrm{g} / \mathrm{mL}$ concentrations and soaked onto the filter paper disc (5 $\mathrm{mm}$ dia.). The antimicrobial activity resulting data are recorded in Table-1.

Table-1: Antimicrobial Activity of Hydrazone Ligand and their $\mathrm{Cu}(\mathrm{II}) \mathrm{Complex}$.

\begin{tabular}{c|c|c|c|c}
\hline \multirow{2}{*}{ Compounds } & \multicolumn{5}{|c}{ Zone of Inhibition (mm) } \\
\cline { 2 - 5 } & B. subtilis & S. typhi & C. tropicalis & A. Niger \\
\hline BHD5 & 8 & 7 & $-v e$ & 7 \\
\hline $\mathrm{Cu}$ (BHD5)Cl & 10 & 8 & 10 & 10 \\
\hline BH5C & $-\mathrm{ve}$ & $-\mathrm{ve}$ & $-\mathrm{ve}$ & $-\mathrm{ve}$ \\
\hline $\mathrm{Cu}$ (BH5C)Cl & 8 & $-\mathrm{ve}$ & 7 & 8 \\
\hline Streptomycin & 20 & 19 & - & - \\
\hline Nystatin & - & - & 19 & 20 \\
\hline \multicolumn{5}{r}{$-v$ (no antimicrobial activity observed) }
\end{tabular}

\section{DPPH Radical Scavenging Assay}

The synthesized hydrazone ligands and their copper complexes were prepared in DMF and take $1 \mathrm{~mL}$ of each compound solution having concentrations $100 \mu \mathrm{g} / \mathrm{mL}$ was added into $4 \mathrm{~mL}$ of $0.1 \mathrm{mM}$ methanol solution of DPPH in a test tube and shaken continuously for clear solution. ${ }^{13}$ Then the test tubes incubated in the dark place for $30 \mathrm{~min}$. The absorbance measured at $517 \mathrm{~nm}$ on a UV-visible spectrophotometer. Ascorbic acid was used as an internal standard. ${ }^{14}$ The results data of DPPH activity are summarized in Table-2. The scavenging assay percentage was calculated using following the formula:

$$
\% \text { Scavenging }=\left[\left(\mathrm{A}_{0}-\mathrm{A}_{1}\right) / \mathrm{A}_{\mathrm{o}} \times 100\right]
$$

Where, $A_{o}$ is the absorbance of without compound, blank and $A_{1}$ is absorbance with the synthesized compound.

Table-2: DPPH Radical Scavenging Assay of Hydrazone Ligand and their Cu(II) Complex

\begin{tabular}{c|c}
\hline Compounds & \% Scavenging \\
\hline BHD5 & 54.4 \\
\hline $\mathrm{Cu}$ (BHD5)Cl & 55.0 \\
\hline BH5C & 56.1 \\
\hline $\mathrm{Cu}$ (BH5C)Cl & 60.8 \\
\hline Ascorbic Acid & 89.1 \\
\hline
\end{tabular}




\section{RESULTS AND DISCUSSION}

The $\mathrm{Cu}(\mathrm{II})$ complexes are colored solid and soluble in DMF and DMSO. Molar conductance $\left[\Lambda_{\mathrm{M}}\right]$ value of $\mathrm{Cu}$ (II) complexes indicated that both the $\mathrm{Cu}$ (II) complexes are non-electrolytes in DMF. ${ }^{15}$ The magnetic moment of $\mathrm{Cu}(\mathrm{BH} 5 \mathrm{C}) \mathrm{Cl}$ complex is $1.94 \mathrm{BM}$ suggesting tetrahedral geometry. ${ }^{5,9}$ The elemental analysis data revealed the formation of 1:1 (Metal: Ligand) complexes.

\section{IR Spectral Studies}

The intermolecular hydrogen bonding vibration $(\mathrm{O}-\mathrm{H}-\mathrm{-N})$ is observed at $3440-3447 \mathrm{~cm}^{-1}$ into the IR spectrum of the ligand which is shifted to the lower frequency at $3415-3434 \mathrm{~cm}^{-1}$ into the complexes, indicated the bonding of the oxygen to the metal ions. ${ }^{15,16}$ The oxygen involves the coordination with metal ions is also conform by the upward shifting of $v(\mathrm{C}-\mathrm{O})$ band at $5-13 \mathrm{~cm}^{-1}$. The exocyclic $v(\mathrm{C}=\mathrm{N})$ of hydrazone functional group $>\mathrm{C}=\mathrm{N}-\mathrm{N}<$ shows the band at $1606-1616 \mathrm{~cm}^{-1}$ which is shifted downward by 6-15 $\mathrm{cm}^{-1}$ after the bonding with metal ions. This change in-band frequency suggesting the nitrogen is involved in coordination with metal ions. ${ }^{17,18}$ This is also supported by the downward shifting of $v(\mathrm{~N}-\mathrm{N})$ stretch in complexes which is observed in free ligand at $1128-1129 \mathrm{~cm}^{-1}$. The endocyclic $v(\mathrm{C}=\mathrm{N})$ of the benzothiazole ring gives the band at $1511-1567 \mathrm{~cm}^{-1}$ which is shifted upward and downward in complexes, suggesting benzothiazole nitrogen is participation in bonding to the metal ions. ${ }^{16,17}$ Some importance band is observed in complexes at $424-428 \mathrm{~cm}^{-1}$ assigned to $v(\mathrm{M}-\mathrm{N})$ and at $569-601 \mathrm{~cm}^{-1}$ assigned to $v(\mathrm{M}-\mathrm{O})$ give the additional support to ligand binding with metal ion. ${ }^{12,18}$

\section{UV-Visible Absorption Studies}

In the UV-Visible spectrum of ligands, two absorption bands are observed at near 274-278 $\mathrm{nm}$ which is conformed the $\pi-\pi^{*}$ transitions of the aromatic ring. ${ }^{19}$ Similarly, $\mathrm{n}-\pi^{*}$ transition of the $>\mathrm{C}=\mathrm{N}<$ azomethine observed near at $381-390 \mathrm{~nm} .{ }^{20}$ Due to the bonding with azomethine nitrogen to the metal ions, these bands are observed at $362-367 \mathrm{~nm}$ in complexes. Also, the band observed at 264-272 $\mathrm{nm}$ in the spectra of complexes assigned to $\pi-\pi^{*}$ transition. ${ }^{21}$ The d-d transitions bands observe at $466-475 \mathrm{~nm}$ which can be accepted charge transfer transitions from ligand to metal ion ${ }^{22}$. UV-Visible resulting data are summarized in Table-3.

Table-3: UV-Visible Spectral Data of Hydrazone Ligand and their Cu(II) Complex

\begin{tabular}{c|c}
\hline Complexes & Wavelength $\left(\lambda_{\max }, \mathrm{nm}\right)$ \\
\hline BHD5 & $278 \pi-\pi^{*}, 381 \mathrm{n}-\pi^{*}$ \\
\hline BH5C & $274 \pi-\pi^{*}, 390 \mathrm{n}-\pi^{*}$ \\
\hline $\mathrm{Cu}($ BHD5)Cl & $264 \pi-\pi^{*}, 367 \mathrm{n}-\pi^{*}, 466 \mathrm{~d}-\mathrm{d}$, LMCT \\
\hline $\mathrm{Cu}($ BH5C)Cl & $272 \pi-\pi^{*}, 362 \mathrm{n}-\pi^{*}, 475 \mathrm{~d}-\mathrm{d}$, LMCT \\
\hline
\end{tabular}

\section{${ }^{1}$ H-NMR Spectral Studies}

The ${ }^{1} \mathrm{H}-\mathrm{NMR}$ spectra are recording in DMSO- $\mathrm{d}_{6}$. The ${ }^{1} \mathrm{H}-\mathrm{NMR}$ spectrums of synthesized ligand compounds show broad signals at $12.87-13.04 \mathrm{ppm}$ due to the $-\mathrm{N} \underline{\mathrm{H}}$ proton. The singlet peaks were observed at 10.51-10.98 ppm indicating phenolic $-\mathrm{OH}$ proton in ligands. The signals observed at 8.39$8.49 \mathrm{ppm}$ responsible for $\mathrm{N}=\mathrm{C}-\underline{\mathrm{H}}$ proton in structure. The aromatic protons $\mathrm{Ar}-\underline{\mathrm{H}}$ shows singlets at $6.93-$ $8.20 \mathrm{ppm}$. The ${ }^{1} \mathrm{H}-\mathrm{NMR}$ spectra of ligands is full agreement with their proposed structure. ${ }^{1} \mathrm{H}-\mathrm{NMR}$ resulting data are summarized in Table-4.

Table-4: ${ }^{1}$ H-NMR Spectrum Resulting Data of Hydrazone Ligand

\begin{tabular}{c|c|c|c} 
Table-4: ${ }^{1} \mathrm{H}-\mathrm{NMR}$ Spectrum Resulting Data of Hydrazone Ligand \\
\cline { 2 - 4 } Ligand & $-\mathrm{N} \underline{\underline{H}}$ & $-\mathrm{O} \underline{\mathrm{H}}$ & $-\mathrm{N}=\mathrm{C}-\underline{\mathrm{H}}$ \\
\hline BHD5 & 13.04 & 10.98 & 8.49 \\
\hline BH5C & 12.87 & 10.51 & 8.39 \\
\hline
\end{tabular}

\section{Mass Spectral Studies}

The mass spectrum data of the ligand BHD5 show the molecular ion peak $\left[\mathrm{M}^{+}\right]$at $\mathrm{m} / \mathrm{z}=382.9 \mathrm{amu}$, which is indicated their molecular mass and $\mathrm{The} \mathrm{Cu}(\mathrm{II})$ complex, $\mathrm{Cu}(\mathrm{BHD}$ ) $\mathrm{Cl}$ show the molecular ion 
peak $\left[\mathrm{M}^{+}\right]$at $\mathrm{m} / \mathrm{z}=481.9$ which is equal to their molecular mass. Some important mass fragmentation peaks observed at $m / z=443.8$ show to $\left[\mathrm{M}^{+}-\mathrm{Cl}\right], m / z=290.9$ for $\left[\mathrm{C}_{11} \mathrm{H}_{6} \mathrm{ClN}_{4} \mathrm{O}_{2} \mathrm{~S}\right], \mathrm{m} / z=194.3$ corresponding to $\left[\mathrm{C}_{7} \mathrm{H}_{4} \mathrm{~N}_{3} \mathrm{O}_{2} \mathrm{~S}\right]$ of benzothiazole moiety and $\mathrm{m} / z=96.9$ corresponding to $\left[\mathrm{C}_{4} \mathrm{H}_{3} \mathrm{NS}\right]$ of thiazole moiety. These molecule ion fragments result indicated 1:1 binding mode between the ligand and $\mathrm{Cu}$ (II) ion in complex. ${ }^{7}$

Similarly, the mass spectrum of the BH5C exhibited the molecular ion peak at $\mathrm{m} / \mathrm{z}=349.01 \mathrm{amu}$ and their $\mathrm{Cu}$ (II) complex, $\mathrm{Cu}(\mathrm{BH} 5 \mathrm{C}) \mathrm{Cl}$ shows the molecular ion peak of $\left[\mathrm{C}_{14} \mathrm{H}_{8} \mathrm{Cl}_{2} \mathrm{~N}_{4} \mathrm{CuO}_{3} \mathrm{~S}\right]\left[\mathrm{M}^{+}\right]$at $\mathrm{m} / \mathrm{z}$ $=445.9 \mathrm{amu}$. Some important mass fragmentation peaks show at $\mathrm{m} / z=408.9$ corresponding to $\left[\mathrm{M}^{+}-\mathrm{Cl}\right]$, $m / z=290.9$ for $\left[\mathrm{C}_{11} \mathrm{H}_{6} \mathrm{ClN}_{4} \mathrm{O}_{2} \mathrm{~S}\right], \mathrm{m} / z=194.03$ corresponding to $\left[\mathrm{C}_{7} \mathrm{H}_{4} \mathrm{~N}_{3} \mathrm{O}_{2} \mathrm{~S}\right]$ of benzothiazole moiety. This mass fragmentation patter reported by many researchers. ${ }^{23,24}$

\section{Thermal Gravimetric Analysis (TGA)}

Thermal studies of $\mathrm{Cu}$ (BHD5)Cl indicate that the complex is stable up to $185{ }^{\circ} \mathrm{C}$. The first stage of decomposition within the temperature range $185-240{ }^{\circ} \mathrm{C}$ may be attributed to the loss of coordinated chloride ion present into the complex structure with an experimental mass loss $7.03 \%$ (theoretical mass loss $=7.25 \%)^{7,25}$ The next successive decomposition at $240-455{ }^{\circ} \mathrm{C}$ due to loss of remaining part of complex contains ligand with an experimental mass loss $75.93 \%$ (theoretical, 76.24\%) goes to the formation of metal oxide i.e $\left[\mathrm{C}_{14} \mathrm{H}_{7} \mathrm{Cl}_{2} \mathrm{~N}_{4} \mathrm{CuO}_{3} \mathrm{~S}\right]$ to $\mathrm{CuO}$.

The thermogram of $\mathrm{Cu}(\mathrm{BH} 5 \mathrm{C}) \mathrm{Cl}$ complex shows the first stage of decomposition within the temperature range $165-240{ }^{\circ} \mathrm{C}$ may be attributed to the loss of coordinated chloride ion present into the complex structure with an experimental mass loss $7.81 \%$ (theoretical mass loss $=7.98 \%$ ). The remaining step of $\mathrm{Cu}(\mathrm{BH} 5 \mathrm{C}) \mathrm{Cl}$ complex decomposition occurs within the temperature range $240-465{ }^{\circ} \mathrm{C}$ may be attributed to the loss of remaining part of complex includes ligand with an experimental mass loss $76.12 \%$ (theoretical, 74.93\%) and remaining $\mathrm{CuO}$ as residue.

\section{Antimicrobial Activity}

The antimicrobial activity was determinate by disk diffusion method ${ }^{26}$ and the results are compared with standard drugs streptomycin (antibacterial) and nystatin (antifungal). The $\mathrm{Cu}(\mathrm{II})$ complexes show good antimicrobial activity than their parent ligand. ${ }^{5,27}$ The complex $\mathrm{Cu}$ (BHD5)Cl shows good activity against all species as compared with other synthesis compounds but least with standard drug.

\section{DPPH Radical Scavenging Assay}

The resulting data of DPPH free radical scavenging assay shows the antioxidant activity of hydrazone ligands enhanced on complexation with $\mathrm{Cu}$ (II) ions. The $\mathrm{Cu}$ (II) complexes show most pronounced DPPH antioxidant activity than parent ligand but less as compared with standard ascorbic acid.

\section{CONCLUSION}

The hydrazone ligands have been prepared by condensation of 6-Nitro-benzothiazole-2-yl-hydrazine and substituted salicylaldehyde. The formation of complexes occurs by reaction of hydrazone ligand and $\mathrm{CuCl}_{2} \cdot 2 \mathrm{H}_{2} \mathrm{O}$ salt. Based on IR spectra, ligands behaviors as $\mathrm{NNO}$ donor tridentate. The complexes show tetrahedral geometry. Thermal analysis reveals the thermal stability of copper complexes. The complexes are biologically active as compared to their parent ligand. The copper complexes exhibited antioxidant activity.

\section{ACKNOWLEDGMENT}

Authors wish to thank the Director, Punjab University providing instrumental facility.

\section{REFERENCES}

1. M. Gulcan, Y. Karatas, S. Is1k, G. Ozturk, E. Akbas and E. Sahin, Journal of Fluorescence, 24, 1679 (2014), DOI: 10.1007/s10895-014-1455-3

2. A. Leoni, A. Locatelli, R. Morigi and M. Rambaldi, Expert Opinion on Therapeutic Patents, 24, 201 (2014), DOI:10.1517/13543776.2014.858121 
3. C. B. Mishra, S. Kumari and M. Tiwari, European Journal of Medicinal Chemistry, 92, 1 (2015), DOI:10.1016/j.ejmech.2014.12.031

4. M. Calinescu and A. Emandi, Molecular Crystals and Liqide Crystals, 415, 247(2004), DOI: $10.1080 / 15421400490482259$

5. D. K. Swamy, S. P. Pachling and T. M. Bhagat, Rasayan Journal of Chemistry, 5, 208 (2012),

6. M. M. Shakdofa. M. H. Shtaiwi, N .Morsy and T. Abdel-rassel, Main Group Chemistry, 13, 187 (2014), DOI:10.3233/MGC-140133

7. R. Bhaskar, N. Salunkhe, Amit Yaul and A. S. Aswar, spectrochimica Acta. Part A: Molecular and Biomolecular Spectroscopy, 151, 1386 (2015), DOI:10.1016/j.saa.2015.06.121

8. K. A. Bai, G. S. Vallinath, K. B. and N. D. Chandrasekhar, Rasayan Journal of Chemistry, 3, 467 (2010)

9. M. V. Angelusiu, S.Barbuceanu, C. Draghici and G. L. Almajan, European Journal of Medicinal Chemistry, 45, 2055 (2010), DOI:10.1016/j. ejmech.2010.01.033

10. A.A. El-Sherif, Inorganica Chimica Acta, 362, 4991 (2009), DOI:10.1016/j.ica.2009.08.004

11. V. Asati, N. K Sahu, A. Rathore, S. Sahu and D. V. Kohli. Arabian Journal of Chemistry, 8, 495 (2015), DOI:10.1016/j.arabjc.2011.01.036

12. W. H Mahmoud, R. G. Deghadi and G. G Mohamed, Applied Organometallic Chemistry, 30, 221 (2016), DOI:10.1002/aoc.3420

13. Y Harinath, D. H. Reddy, B. N. Kumar, Ch Apparao and K Seshaiah, spectrochimica Acta. Part A: Molecular and Biomolecular Spectroscopy, 101, 264 (2013), DOI:10.1016/j.saa.2012.09.085

14. N. Naik, H. Vijay Kumar, J. Rangaswamy, S.T. Harini and T.C. Umeshkumar, Journal of Applied Pharmaceutical Science, 2, 67 (2012), DOI:10.7324/JAPS.2012.21112

15. D. Gurbuz, A. Cinarli, A. Tavman and A. Seher Birteksoz, Bulletin of the Chemical Society of Ethiopia, 29, 63 (2015), DOI:10.4314/bcse.v29i1.6

16. N. Chitrapriya, V. Mahalingam and M. Zeller, K. Natarajan, Inorganica Chimica Acta, 363, 3685 (2010), DOI:10.1016/j.ica.2010.05.017

17. A. M. Hammam, S. A. Ibrahim, M. H. Abo Elwafa, M. A. El-Gahami and W. Thabet, Synthesis and Reactivity in Inorganic and Metal-Organic Chemistry, 22, 1401 (1992), DOI: $10.1080 / 15533179208017851$

18. M. Mishra, K. Tiwari, P. Mourya, M. M. Singh and V. P. Singh, Polyhedron, 89, 29 (2015), DOI: 10.1016/j.poly.2015.01.003

19. S. Y. Ebrahimipour, I. Sheikhshoaie, J. Castro, W. Haase, M. Mohamadi, S. Foro, M. Sheikhshoaie and S. E. Mahani, Inorganica Chimica Acta, 430, 245 (2015), DOI:10.1016/j.ica.2015.03.016

20. B. Anupama, M. Sunita, D. S. Leela, B. Ushaiah and C. G. Kumari, Journal of Fluorescence, 24, 1067 (2014), DOI:10.1007/s10895-014-1386-z

21. J. D. Chellaian and J. Johnson, spectrochimica Acta. Part A: Molecular and Biomolecular Spectroscopy, 127, 396 (2014), DOI:10.1016/j.saa.2014.02.075

22. N. Salem, L. El-Sayed and M.F. Iskander, Polyhedron, 27, 3215 (2008), DOI: 10.1016/j.poly.2008.07.009

23. N. Ahmed, M. Riaz, A. Ahmed and M. Bhagat, International Journal of Inorganic Chemistry, 1 (2015), DOI:10.1155/2015/607178

24. J. S. McIndoe and K. L. Vikse, Journal of Mass Spectrometry., 54, 466 (2019), DOI: $10.1002 / \mathrm{jms} .4359$

25. O. M.I. Adly and A. Taha, Journal of Molecular Structure, 1038, 250 (2013), DOI: $10.1016 /$ j.molstruc.2013.01.035

26. M. Idrees, S. Kola and N. J. Siddiqui, Rasayan Journal of Chemistry, 12, 1723 (2019), DOI: 10.31788/RJC.2019.1245467

27. Y. Satyawana, R. Meena, R. V. Singh and N. Fahmi, Rasayan Journal of Chemistry, 12, 2328 (2019), DOI: $10.31788 /$ RJC.2019.1245459

[RJC-5606/2019] 